\title{
A FENNTARTHATÓ FOGYASZTÁS IRÁNT ELKÖTELEZETT FOGYASZTÓK MEGJELENÉSE MAGYARORSZẢGON
}

\author{
Rácz Georgina' ${ }^{1}-$ Dr. Horváth Ágnes ${ }^{2}$ \\ 'Ph.D. hallgató, Szent Istvản Egyetem, Marketing Intézet, Gödöllō \\ ${ }^{2}$ egyetemi docens, Szent István Egyetem, Marketing Intézet, Gödöllõ
}

\section{SUMMARY}

Nowadays the significance of the concept of sustainable consumption is getting harder, which assumes the appearance of the conscious consumers. In the first part of this study based on international literature we introduce the main behavioural characteristics of the LOHAS, and according to the domestic literature we examine the relevance of the LOHAS concept in Hungary.

In the second part results of a research (conducted within the framework of a country level representative data collection) carried out in September, 2011 by Cognative Ltd. are being introduced, which shows that values on the path of sustainability have also appeared in Hungary. Finally we pointed out that the trend follower consumer groups in Hungary assign new market opportunities and risks for companies with homogenous products.

Key words: representative data collection, sustainable consumption, LOHAS, value-based lifestyle segmentation

\section{BEVEZETÉS}

A globális kihívásokra reflektálva egyre nagyobb jelentőséget kap a fenntartható fejlödés, illetve az egyének szintjén megjelenő fenntartható fogyasztás. A fenntartható fogyasztás iránt leginkább elkötelezett fogyasztói csoportnak a LOHAS (Lifetyle of health and sustainability) tekinthetō. A külföldi szakirodalomi megközelítések szerint ezek a fogyasztók vásárlási döntéseiknél a fenntartható fejlődés mindhárom - gazdasági, társadalmi és ökológiai- pillérét figyelembe veszik. Fontos, hogy az új típusú fogyasztók motivációi a konkrét vásárlási szituációkban is megjelenjenek, ezzel kifejezve a változtatás iránti igényüket. E megállapítás az élelmiszeripari vállalatokat is újabb kihívások elé állitja. Egyrészt azért, mert versenyelönyt jelenthet a differenciálatlan termékek piacán a speciális fogyasztói igények kielégítését szolgáló, sajátos hozzáadott értékkel bíró élelmiszerek kínálata. Másrészt az ủj fogyasztói magatartástrend megjelenése felhívja a figyelmet arra, hogy további piacvesztés elkerülése érdekében, mihamarabb el kell kezdeni átszervezni a vállalati müködést a fenntarthatóság elveinek megfelelően.

\section{IRODALMI ÁTTEKINTÉS}

Az NMI (Natural Marketing Institute) szegmentációs modellje alapján a LOHAS fogyasztó a következő sajátosságokkal bír: attitüdjében a leginkább meghatározó elemek a környezet, a társadalom és a felelös üzletvitel iránti elkötelezettség. A vásárlás szempontjából korai elfogadók, képesek befolyásolni családjuk és barátaik véleményét, kevésbé árérzékenyek, és jellemzően márkahüek. (French-Rogers, 2006). A fenntarthatóság elkötelezettjei, de fontos vásárlási kritérium számukra a stílus és az esztétikum, azaz a hedonizmust sem utasítják el. (Kreeb et. al, 2008). A Zukunftistitute, kutatásai alapján a LOHAS csoport a minőséget felértékeli, és az autentikus értékeket fontosabbnak tartja az élménykeresésnél. Számukra az anyagi javak felhalmozásának fontosságát felváltja a létezés, a lélek jelentősége. Nemcsak egészségtudatosak, hanem jelentős mértékben figyelnek, annak természetre és a társadalmi igazságosságra gyakorolt hatására. Nem az a céljuk, hogy bojkottálják a nem fenntartható módon előállított termékek fogyasztását, hanem egyéni vásárlóerejükkel egy globális ökológiai és társadalomközpontú szemléletváltást kívánnak 
elérni. (Kreeb et. al, 2008). A fentiek alapján elmondható, hogy a LOHAS fogyasztó hibrid életstílust alakít ki, melyben különböző, karakterisztikák egyesülnek (pl. egészség és élménykeresés, individualizmus, de nem egocentrikusság). Ezek, a részben egymással ellentétes tulajdonságok jellemzik a posztmodern fogyasztó értékorientált életstílusát. (Schulz 2008). Paul Ray (1996) az amerikai LOHAS csoport esetén megállapította, hogy képviselői főként a nők köréből, valamint jellemzően a felső- és közép társadalmi osztályból kerülnek ki.

A LOHAS fogyasztó tudatában van a vásárlás kockázatának, ezért nagy jelentőséget tulajdonít a megbízható információknak, döntését megfontolt, aprólékos információgyüjtés és értékelés előzi meg. Az élelmiszergyártó és forgalmazó vállalatoktól elvárja a teljes folyamat átláthatóságát. Számukra különösen felértékelődnek a következő tényezők: élelmiszerjelölések (pl. összetevők listája, tápérték címke, védjegyek); továbbá a vállalatok CSR tevékenysége, mely számukra az etikus magatartást jeleníti meg. (French-Rogers, 2005)

A hazai szakirodalomban eddig nem jelent meg olyan publikáció, amely a magyar LOHAS szegmens lakosságon belüli arányát konkretizálná, magatartásjegyeit azonosítaná. Arra viszont számos hazai publikáció utal, hogy az un. „hibrid életstílust” jellemző egészségtudatosság, környezet tudatosság, és etikus fogyasztás bizonyítottan megjelent már a magyar lakosság körében is (Horváth et al., 2005; Hofmeister Tóth et al. 2010; Gulyás, 2008).

\section{ANYAG ÉS MÓDSZER}

2010-ben kvalitatív kutatást hajtottunk végre, melyben a Magyarországon is megjelenő általános nöi magazinokat a tartalomelemzés módszerének segítségével vizsgáltuk. Kutatásunk során igyekeztünk feltárni, hogy a hazai véleményvezető médiumok milyen mértékben célozzák meg a LOHAS érdeklődésü fogyasztókat. E kutatás eredményei alapján állítottuk össze azt az állításlistát, mely az 1.sz táblázatban ismertetésre kerül. Az állítások logikai szempontból az alábbi 5 tényezöcsoportba (dimenzióba) rendezhetök: környezettudatosság, egészségtudatosság, etikus magatartás, autentikus értékek, individualizmus.

Az adatfelvételre 2011 szeptemberében a Cognative Piackutató Kft. Omnibus 2011 kutatásának keretében került sor, 1015 fö megkérdezésével. A mintavétel a szigorított véletlen séta módszerével történt, a település és megyék alapján kialakított, rétegzett mintavétel segítségével, 111 mintavételi pont alkalmazásával. Az adatfelvétel után bevitt és megtisztított adatokat az SPSS 16.0 statisztikai szoftver segítségével dolgoztuk fel.

\section{EREDMÉNYEK}

\subsection{A FENNTARTHATÓSÁG IRÁNYẢBA MUTATÓ ÉRTÉKEK A MAGYAR FOGYASZTÓK KÖRÉBEN}

Az öt életstílus-dimenziót képviselő állításlistát faktorelemzés segítségével megvizsgáltuk és az eredmények azt bizonyítják, a magyar fogyasztók körében is tetten érhetỏ a hibrid életstílust kifejezỏ értékstruktúra, amelyben fontos szerephez jutnak a fenntarthatóság irányába mutató értékek is. A faktorelemzés eredményeként a hazai fogyasztókat jellemzö értékstruktúra számos sajátos vonást jelez az eredeti koncepcióhoz képest. Az egyik meglepő sajátosság, hogy az egészség és környezettudatos magatartást megjelenítő értékek egy faktorba kerültek, tehát ez a két magatartásforma szoros kapcsolatban van egymással a magyar fogyasztók értékrendjében. A másik említést érdemlö sajátosság, hogy a hazai fogyasztók életmódmintázatában az etikus értékek faktorokba történő rendeződése azon alapult, hogy a vásárlók önmagukat kompetensnek érzik-e az adott állítás szempontjából. (1. táblázat)

1. faktor - Individualista értékek (magyarázott variancia: 19,918\%): Az állításlistában 1925. értékek. 
2. faktor - Egészség-és környezettudatos értékek (magyarázott variancia: 19,554\%): Az állításlistában 1-9. értékek. Fontosnak tartjuk kiemelni, hogy a környezettudatos értékek (egy kivétellel) rendre kisebb súllyal szerepelnek, mint az egészségtudatosságot kifejező állítások, azaz a magyar fogyasztók értékrendjét az egészségtudatosság erőteljesebben áthatja.

3. faktor - Autentikus értékek (magyarázott variancia: 4,836\%): Az állitáslistában 15-18. értékek. A harmadik faktorba olyan autentikus értékek kerültek, melyek a fogyasztók nemzeti elkötelezettségét, biztonság iránti vágyát fejezik ki.

4. faktor - Etikus (kompetencia) értékek (magyarázott variancia: 3,119\%): Az állításlistában 10., 11. és 14. értékek. A negyedik faktor arra utal, hogy az etikus kompetencia értékeket a magyar fogyasztók nem tartják igaznak önmagukra nézve, tehát nem, vagy csak bizonyos részüket jellemzi az etikus magatartás konkrét cselekvéseikben.

5. faktor - Etikus (vállalati magatartásra vonatkozó) értékek (magyarázott variancia: 3,069\%): Az állításlistában 12-13. értékek. Ebben a dimenzióban két olyan tényezỏ jelenik meg, melyek a vállalati magatartás megítélésére vonatkoznak. Ezeket a fogyasztó saját kompetenciáján kívülinek tekinti.

\subsection{FENNTARTHATÓSÁG ÉRTÉKRENDJÉN ALAPULÓ ÉlETSTÍlUS} SZEGMENSEK

A faktor elemzés elvégzése után a magyar fogyasztók érték alapú életstílusszegmentációja céljából klaszter analízist hajtottunk végre. A minta nagy elemszámára $(\mathrm{N}=1015)$ tekintettel az elemzés lefolytatásához k-means módszert alkalmaztuk. A k-means eljárás elvégzése után a következő csoportok különültek el: 1. klaszter : Idős tudatosak; 2. klaszter:Trendkövetök; 3. klaszter: Nemzeti elkötelezettséggel rendelkezó egészség- és környezettudatosak; 4. klaszter: Közömbösek; 5. klaszter: Csalódott pesszimisták. (1. táblázat)

A fenti csoportok közül a „Trendkövetők” értékrendje igazodik a leginkább a LOHAS fogyasztót jellemzö hibrid életstílushoz. Egészség- és környezettudatosak, továbbá az etikus értékek esetén nem csak a társadalomközpontú vállalati magatartást tartják fontosnak, hanem a kompetencia értékeket is (pl. önkéntesség, állatkísérletektől mentes termékek vásárlása). További sajátossága e fogyasztói csoportnak, hogy valamennyi szegmens közül ök tekinthetők a leginkább individualistának, miközben az autentikus értékeket is fontosnak tartják.

Fontos kiemelni, hogy a „Trendkövetök” szegmensét még nem tekinthetjük teljes mértékben elkötelezett LOHAS fogyasztóknak, ugyanis esetükben kritikus pontot jelez az etikus (kompetencia) értékek megitélése. A részletesebb elemzések eredményei arra utalnak, hogy e dimenzió tényezőivel szemben inkább közömbösnek mondhatók, mint elhivatottnak. Szükségesnek tartottuk tehát a "Trendkövetők" csoportjảhoz tartozó fogyasztók véleményének alaposabb vizsgálatát, amelyet az adott részmintán belüli további szegmentálás keretében végeztünk el. (A klaszterképzést ez esetben is a k-means eljárással hajtottuk végre, az F-próba szignifikanciaszintje az elvárásoknak megfelelöen kisebb volt, mint 0,05 , mely igazolta a homogén csoportok létrejöttét).

A „Trendkövetők” szegmensén belül hat fogyasztói alcsoportot lehetett elkülöníteni, közülük kettő olyan alkalszter, melyek az etikus (kompetencia) értékeket a csoportátlaghoz képest jelentósen felülértékelték. E két alklaszter a LOHAS fogyasztót jellemző hibrid életstílust megjelenítő, értékcsoportokat inkább igaznak tartotta önmagára nézve, részarányuk a teljes mintához viszonyítva 4\%-t, ill. 3,6\%-t képviselt. A két alklaszter közt némi különbség fedezhető fel abból a szempontból, hogy az egyes életmód dimenziókat képviselő értékeket, hogyan ítélték meg, de ezek az eltérések nem voltak számottevők.

Megállapítható továbbá, hogy a fenntartható fogyasztás kritériumait kisebb-nagyobb mértékben szem elött tartó fogyasztók aránya ma Magyarországon 21\% (a potenciális piac), 
melyet az un. „Trendkövetők” csoportja jelenít meg. E csoporton belül azonosítható a LOHAS szegmens, melyet legkarakteresebben az etikus (kompetencia) értékek alapján lehet elkülöníteni, és arányuk a teljes lakosságon belül 4-8\%.

\section{KÖVETKEZTETÉSEK, JAVASLATOK}

Kutatásunk eredményei azt jelzik, hogy a hazai fogyasztók értékrendjében az egészség- és környezettudatosság kiemelt jelentőséggel bír. A vásárlók különösen fontosnak tartják az élelmiszer összetevök élettani hatásaival kapcsolatos megbízható információkat, és a körülményekhez képest igyekeznek tartózkodni az adalékanyagokat tartalmazó termékektől. A vásárlási döntés során az általuk egészségesnek tartott élelmiszereket részesítik elönyben, de azt is fontosnak tartják, hogy a termék ne szennyezze a környezetet. Egyre inkább jellemző, hogy a magyar fogyasztók nemzeti elkötelezettségüket (etikus érték) juttatják kifejezésre a magyar termékek preferálásával.

Ezek az eredmények azt bizonyítják, hogy a hazai piacon versenyelönnyel rendelkeznek az olyan hazai, egészséges- és környezetbarát termékek, melyek egyben individualista értékeket is megjelenítenek, pl. valamilyen szempontból egyediek (tájjellegü termékek), vagy a márkák megkülönböztetésre alkalmas tulajdonsággal rendelkeznek.

A nemzetközi fogyasztói magatartás trendek tapasztalatai és a kutatásunk eredményei alapján elöre jelezhető, hogy a magyar fogyasztók körében is hamarosan megjelenik egy olyan vevöi kör, amelyik a vásárláskor elönyben részesíti azokat a termékeket, amelyek elöállítása során -hitelt érdemlően bizonyított- az etikus vállalati magatartás. Természetesen az etikus értékek a fogyasztói elvárásokban akkor fognak igazán testet ölteni, ha a piaci folyamatokról nemcsak széleskörü, hanem hiteles és megbízható tájékoztatást kapnak a vevök.

A nagy-elemszámú és reprezentatív mintán végzett kutatási eredményeink azt bizonyítják, hogy az élelmiszeripari vállalatok szempontjából új paci lehetőségeket jelenthetnek a "Trendkövetők", mint potenciális LOHAS fogyasztók. Bár a szorosan értelmezett LOHAS fogyasztók jelenleg kis arányt képviselnek a teljes lakosságon belül, jelenlétük azonban már ma is figyelmet érdemel. A fenntarthatóság iránti elkötelezettség trendjének további terjedését feltételezve, az élelmiszergyártóknak és forgalmazóknak is érdemes felkészülniük a LOHAS csoport vásárlását jellemző kritikus szemléletmódra, és az elvárt kritériumoknak megfelelően átalakítani vállalati folyamataikat. 
1. táblázat: Értékrend alapú fogyasztói csoportok

\begin{tabular}{|c|c|c|c|c|c|c|c|c|}
\hline Tényezök & $\mathbf{F}$ & sig & $\begin{array}{c}\text { Mintaátlag } \\
\mathrm{N}=1015\end{array}$ & $\begin{array}{c}1 . \\
\text { klaszter } \\
\mathrm{N}=176 \\
17 \% \\
\end{array}$ & \begin{tabular}{|c|}
2. \\
klaszter \\
$\mathrm{N}=212$ \\
$21 \%$ \\
\end{tabular} & \begin{tabular}{|c|}
3. \\
klaszter \\
$\mathrm{N}=275$ \\
$27 \%$ \\
\end{tabular} & \begin{tabular}{c|}
4. \\
klaszter \\
$\mathrm{N}=192$ \\
$19 \%$ \\
\end{tabular} & $\begin{array}{c}5 . \\
\text { klaszter } \\
N=160 \\
16 \% \\
\end{array}$ \\
\hline 1. Fontos, hogy a megvásárolt termék csomagolása újrahasznositható legyen. & 74,724 & 0,000000 & 3,992 & 4,488 & 4,439 & 4,136 & 3,352 & 3,374 \\
\hline 2. Az cnergiatakarékos háztartási berendezések hozzájárulnak a fenntartható fejlödéshez. & 73,003 & 0,000000 & 4,045 & 4,566 & 4,340 & 4,194 & 3,445 & 3,544 \\
\hline 3. Szüksćges, hogy a gyerekek kornyezettudatos neveléshen részesüljenek. & 128,117 & 0,000000 & 4,334 & 4,864 & 4,597 & 4,650 & 3,506 & 3,853 \\
\hline $\begin{array}{l}\text { 4. Elönyben részesitem az olyan élelmiszereket, melyek hozzájárulnak egészségem } \\
\text { megôrzéschez. }\end{array}$ & 108,108 & 0,000000 & 3,930 & 4,466 & 4,473 & 4,133 & 3,185 & 3,163 \\
\hline $\begin{array}{l}\text { 5. Napi étkezéseim tervezésekor figyelek arra, hogy megfelelö mennyiségben hozzájussak a } \\
\text { szervezetem számára nélkülözhetetlen tápanyagokhoz. }\end{array}$ & 74,328 & 0,000000 & 3,739 & 3,967 & 4,414 & 3,898 & 3,116 & 3,055 \\
\hline 6. Az egészség megörzéséhez nélkülözhhtetlen a sport. & 88,088 & 0,000000 & 3,846 & 4,146 & 4,439 & 4,093 & 3,173 & 3,112 \\
\hline 7. Rendszerint szezonális termékeket (pl, dinnye augusztusban) vásárlok. & 70,038 & 0,000000 & 3,845 & 4,240 & 4,415 & 3,983 & 3,137 & 3,267 \\
\hline 8. Az èlelmiszerekben megtalálható adalékanyagok kárositják az egészségemet. & 116,212 & 0,000000 & 3,956 & 4,496 & 4,431 & 4,137 & 3,169 & 3,367 \\
\hline $\begin{array}{l}\text { 9. Az egészséges táplálkozás szempontjából fontos, hogy az ember tisztában legyen az élelmiszer } \\
\text { osszetcuök (pl. vitaminok, cukrok, telitett zsirsavak stb.) élettani hatásaival. }\end{array}$ & 118,298 & 0,000000 & 3,944 & 4,536 & 4,356 & 4,151 & 3,230 & 3,247 \\
\hline 10. Rendszerint adományokkal támogatom a civil szervezetek munkáját. & 76,77 & 0,000000 & 2,157 & 1,924 & 2,784 & 1,647 & 2,964 & 1,488 \\
\hline 11. Évente vćgzek önkéntes munkát & 109,083 & 0,000000 & 2,072 & 1,385 & 2,833 & 1,613 & 2,997 & 1,492 \\
\hline 12. Kedvezöbben itélem meg azt a vállalatot, mely jótékonysági akciókat támogat. & 79,259 & 0,000000 & 3,440 & 3,932 & 4,170 & 3,333 & 3,196 & 2,41 \\
\hline $\begin{array}{l}\text { 13. Kedvezb̋bben itélem meg azi a vállalatot, mely megfelelö munkakörülményeket biztosit } \\
\text { alkalmazottai számára. }\end{array}$ & 92,013 & 0,000000 & 3,832 & 4,498 & 4,345 & 3,918 & 3,240 & 2,981 \\
\hline 14. Kizárólag állatkisérletektöl mentes termékeket vásảrolok. & 57.23 & 0,000000 & 3,107 & 3,113 & 4,003 & 2,751 & 3,166 & 2,458 \\
\hline 15. Ha a helyi piacokon vásárolok élelmiszert, akkor avval a magyar termelöket támogatom. & 101,188 & 0,000000 & 3,815 & 4,461 & 4,404 & 3,762 & 3,157 & 3,204 \\
\hline 16. Fontos számomra a hagyományok tisztelete. & 97,06 & 0,000000 & 3,870 & 4,688 & 4,263 & 3,888 & 3,155 & 3,280 \\
\hline 17. Magyar termékek vásárlásával hozzájárulok az ország gazdasági fejlődéséhez. & 90,879 & 0,000000 & 3,927 & 4,508 & 4,318 & 4,125 & 3,172 & 3,337 \\
\hline $\begin{array}{l}\text { 18. A termékeken szereplö védjegyek (pl. magyar termék) csókkentik bizonytalanságomat a } \\
\text { vásárlás során. }\end{array}$ & 76,718 & 0,000000 & 3,724 & 4,275 & 4,226 & 3,810 & 3,088 & 3,068 \\
\hline 19. Fontos számomra a karrier. & 235,553 & 0,000000 & 2,940 & 1,520 & 4,104 & 3,275 & 3,224 & 2,039 \\
\hline 20. A márkás termékeket részesitem elönyben. & 282,463 & 0,000000 & 2,826 & 1,493 & 3,952 & 2,948 & 3,463 & 1,824 \\
\hline 21. Az egyedi kivitelezésü termékeket kedvelem. & 361,051 & 0,000000 & 2,859 & 1,497 & 4,258 & 2,940 & 3,349 & 1,772 \\
\hline 22. Fontos számomra a stilus. & 314,94 & 0,000000 & 3,074 & 1,732 & 4,338 & 3,312 & 3,498 & 1,962 \\
\hline 23. A legújabb divat szerint alakitom életvitelemet. & 340,52 & 0,000000 & 2,599 & 1,203 & 3,876 & 2,469 & 3,422 & 1,677 \\
\hline 24. Olyan termékeket vásárlok, melyek tükrozik személyiségemet. & 219,964 & 0,000000 & 3,097 & 2,022 & 4,275 & 3,278 & 3,405 & 2,035 \\
\hline 25. A magas minöségü termékeket kedvelem. & 132,702 & 0,000000 & 3,175 & 2,414 & 4,188 & 3,291 & 3,333 & 2,278 \\
\hline
\end{tabular}




\section{FELHASZNÁLT IRODALOM}

French, S. - Rogers, G. (2005): Marketplace Opportunities:Growth \& Demographic Opportunities. Natural Marketing Institute, USA, Harleysville

French, S. - Rogers, G. (2006): Understanding the LOHAS Consumer: The Rise of Ethical Consumerism, Natural Marketing Institute, USA, Harleysville

Gulyás E. (2008): Az etikus fogyasztás értelmezései, Szociológiai Szemle, 19. évf., 2008/1. sz. 106-127. o.

Hofmeister Tóth Á. - Kelemen K. - Piskóti M. (2010): Környezettudatos fogyasztói magatartásminták a magyar háztartásokban. Magyar Marketing Szövetség 16. Országos Konferenciája, „Új Marketing Világrend”. 2010. augusztus 26-27. Budapest.

Horváth Á. - Fürediné K. A. - Fodor M. (2005): Az értékrend hatása a táplálkozásra, The Hungarian Journal of Food, Nutrition and Marketing, 2005/1-2. sZ.

Kreeb, M. - Motzer, M. - Schulz, W. F. (2008): LOHAS als Trendsetter für das Nachhaltigkeitsmarketing, in Schwender, Clemens; Schulz, Werner \& Kreeb, Martin (Hrsg.) (2008): Medialisierung der Nachhaltigkeit. Das Forschungsprojekt balance(f): Emotionen und Ecotainment in den Massenmedien. Marburg: Metropolis.

Ray, P. (1996): The Rise of Integral Culture, Notice Science Review, 1996/37

Schulz, W. F (2008): Der Markt für nachhaltige Produkte, Eine Chance für den Mittelstand, Vortrag im Rahmen der BMZ/DIHK - Auftakveranstaltung „Mittelstand schaft Werte” am 6. Dezember 2008 in Berlin im Haus der Deutschen Wirtschaft 